\title{
F. M. DOSTOEVSKY AND NIHILISTIC INTERPRETATION OF HOLBEIN'S PAINTING „DEAD CHRIST IN THE TOMB”
}

\author{
Daniel Miščin, Faculty of Philosophy and Religious Sciences, University \\ of Zagreb, Croatia,dmiscin@ffrz.unizg.hr
}

Original scientific paper

DOI: 10.31902/fll.38.2021.3

\begin{abstract}
Ever since Hans Holbein the Younger completed his painting, The Dead Christ in the Tomb, in 1522, a question has been looming over it, namely, what message does this dead body convey? Having seen the painting in 1847 , the Russian classic writer Fyodor Dostoevsky was also intrigued by this question. In his novel, The Idiot, Ippolit Terentyev seeks to give a systematic and direct answer. The article presents a hermeneutic analysis of his position, and classifies it as nihilistic. Nihilism affects all three levels of Ippolit's discourse - the ontic, eschatological and ontological. Nevertheless, the question remains: can such nihilism be justified from the perspective of the painting itself? Posing this question in the context of Alois Riegl's periodization of European culture has proven to be interesting. He is of the opinion that, following the era of Christian monotheism, the third and the last period of the development of European culture is the natural-scientific period. This particular period, Riegl believes, began in 1520. If we choose to accept this periodization model, The Dead Christ may be seen as one of the first paintings of the modern era, keeping in mind that Holbein painted it in 1521 and 1522. As regards the issue of the body of The Dead Christ being immersed in physical suffering to the extent that the possibility of resurrection is excluded - as Ippolit presumes - this article offers certain reasons of an anatomical nature which may be interpreted theologically and which deny the validity of Ippolit's modern, nihilistic hypothesis in regard to the meaning of Holbein's Dead Christ.
\end{abstract}

Keywords: Dostoevsky; Holbein; Ippolit Terentyev; death; nihilism; Jesus Christ; resurrection.

\section{Introduction: The formulation of a hypothesis}

What is Fyodor Mihailovich Dostoevsky's relation to the painting The Dead Christ in the Tomb by Hans Holbein the Younger? ${ }^{1}$ In the literature on Dostoevsky, this question is customarily addressed from a historical, chronological perspective. There are three stages in his life during which this relationship came into being, was developed and shaped.

${ }^{1}$ Hans Holbein the Younger: The Body of the Dead Christ in the Tomb (15211522), Oil and tempera on linden wood, $30.5 \mathrm{~cm} \times 200 \mathrm{~cm}$, Kunstmuseum Basel. 
Accordingly, the citing of Karamzin's Letters of the Russian Traveler as the first of these stages is inevitable. It is on these pages that Dostoevsky first discovered references to Holbein's Dead Christ (Karamzin 1984, 98). Then there is the usual biographical information according to which Dostoevsky, on his way to Geneva in August 1867, stopped in Basel solely to see this painting (Bitjugova 1999, 129). Dostoevsky's wife reminisced on this important moment in his life in two texts: her Diary of the Year 1867 (Dostoevska 1993, 234) and her subsequent Reminiscences (Dostoevska 1987, 186). The third and crucial stage is actually the culmination of Dostoevsky's relationship to Holbein's Dead Christ in the novel The Idiot. A fourth stage might be added to the preceding three. Namely, as I endeavoured to demonstrate in an earlier article (Miščin 2020, 297-309), it seems that Alyosha Karamazov's torments before the dead body of Starets Zosima in The Brothers Karamazov are in fact a continuation of Dostoevsky's own struggle with Holbein's Dead Christ.

This article focuses on the third of these stages, i.e., Holbein's Christ in the novel The Idiot. In philosophically inspired scientific literature one can often encounter the thesis that this painting is the main theme and the "greatest challenge" of the whole novel (Pattison 2002, 183; Frank $2009,549)$. In line with this thesis, it is not surprising that the image dominating the book cover of one of the most prestigious contemporary British editions of The Idiot is that of the head of Christ from Holbein's painting (Dostoevsky 2008). This painting is, without a doubt, present in the pages of the novel in many ways. However, the characters in the novel only rarely refer to it explicitly and in detail, with the exception of one - only seemingly secondary - character, namely, Ippolit Terentyev. This article therefore focuses on what could be called "Ippolit's argument" in view of gaining an understanding of the meaning of Holbein's Dead Christ. It attempts to formulate a hermeneutic key for an understanding of this argument. In this context, the initial, most common question about the relationship between Dostoevsky and Holbein needs to be reshaped and replaced with a different, more precise and challenging one: what does Holbein's Dead Christ actually mean in the novel The Idiot - what message does it convey? In an effort to answer this question, Prince Mishkin's famous claim, namely, that it is possible for one to lose faith by looking at this painting, is frequently cited (Dostoevsky 1973, 182). ${ }^{2}$ Although Prince Mishkin is obviously

2 The quotations from Dostoevsky's work in this review are based on the Russian critical edition, with the usual abbreviation PSS, volume number and page number. Complete bibliographic data can be found in the bibliography. 
preoccupied with this dark foreboding, he is not able to be more specific. Someone else will do it in his stead - Ippolit Terentyev.

He presents his grasp of this painting in the fourth chapter of part three of The Idiot (PSS 8, 338-339). The sharpness of Ippolit's reflection on The Dead Christ is comparable to that of Ivan Karamazov in his discussion on the theodicy implications of a child's suffering. If Ivan's thoughts are analysed from the metaphysical perspective, it becomes obvious that his rebellion is directed against Leibniz's theodicy. Moreover, Ivan's "returning the ticket for this world" is a direct consequence of a violation of the moral sense with respect to the ontology of the created world (Miščin 2011, 167-280). He declares, in a seemingly conciliatory way, that he acknowledges God but not the world He has created (PSS 14, 338-339). The question that lurks behind this apparent reconciliation cannot be suppressed: if the suffering of children is really sufficient reason to reject the world, how does this rejection relate to God's being? In other words, is it really possible to "return the ticket" without simultaneously overthrowing God?

Regardless of the possible answer to this question, it is interesting to approach Ippolit Terentyev's doubts about the Dead Christ in The Idiot in the context of Ivan's rebellion in The Brothers Karamazov. Ippolit also does not exclude God, but rejects the created world, and there he is completely in line with Ivan's thoughts (Frank 2020, 150). Indeed, although Ivan discusses the suffering of children and Ippolit the suffering of Christ, the problem behind both of these debates is actually the same: both of them question the meaning and ultimately the permissibility of the suffering of the innocent, whether it be that of a child or of Christ. This is essentially a question of theodicy which takes both Ippolit and Ivan in the same direction: even if the idea of God is not completely destroyed by Ivan's demonstrative "returning the ticket" or by Ippolit's doubts when facing Holbein's Christ, do they not, in both cases, undermine some of the fundamental attributes of God? Does the suffering of the innocent not call into question God's righteousness, mercy and, indirectly, omnipotence? Finally, there is another similarity between Ivan's and Ippolit's thinking, namely, the manner in which Ivan and Ippolit answer these questions brings them close to nihilism. In Ippolit's case, this seems to be the case even more directly.

When undertaking an analysis of Ippolit's reflections on the Dead Christ, one must start by confirming the obvious. Ippolit believes that this image depicts Christ who „made himself nothing by taking the very

Literal quotations (in quotation marks) are given in accordance with the English translation. 
nature of a servant being made in human likeness" (Phil 2,7). He believes that Holbein's Christ not only proves what theology calls kenosis (Brouwer 2002, 69-108) but goes a step further. His greatest struggle is the view that this dead body of Christ calls into question the very possibility of His resurrection (PSS 8,239$).{ }^{3}$ In Ippolit's view, the extent to which Holbein's Christ is bruised and battered suggests the supremacy of nothingness. This would mean that Holbein actually represents the body of the dead Christ that "got stuck" on Holy Saturday in a place where there is no passageway towards the following morning and resurrection. Julia Kristeva perhaps best summed up Ippolit's thoughts in a very precise sentence: „A sense of time abolished weighs on that picture, the inescapable prospect of death erasing all commitment to a project, continuity or resurrection" (Kristeva 2003, 188). For the purposes of this article, the hypothesis about the meaning of Holbein's Christ in The Idiot is called "nihilistic", and Ippolit Terentyev is considered a true spokesman thereof.

Unlike Ivan Karamazov, Ippolit Terentyev did not fully develop the theoretical foundations of his nihilism. His thinking is nevertheless extremely rich in theological and especially (post-) metaphysical implications. Although Ippolit is most often classified as a supporting character in The Idiot, Dostoevsky is fully aware of the significance of his thoughts. This is clearly evidenced by the notes written between August 1868 and January 1869. Dostoevsky writes: „Ippolit - the main axis of the whole novel" and furthermore, "Write tersely and powerfuly about Ippolit. Center the whole plot on him" (Wasiolek 2017, 233-234). With this in mind, the first task of this article is to elucidate the metaphysical implications of Ippolit's confrontation with Holbein's Christ. Once they are outlined, they need to be verified again by confronting them with the painting itself, Holbein's Dead Christ.

\section{The hermeneutics of Ippolit Terentyev's nihilistic message about Holbein's Christ}

The structure of Ippolit Terentyev's argument about Holbein's Dead Christ consists of three levels. Each subsequent level is broader than the previous one.

\footnotetext{
${ }^{3}$ Ippolit's point of departure is that the painting is a depiction of Christ who has just been taken down from the cross (PSS 8, 339). This, however, can be called into question, since signs of the beginning of tissue decay are clearly visible, especially in the area of the wound on the arm, which implies a longer lapse of time since death occurred.
} 
Firstly, Ippolit wonders how the disciples could have believed looking at such a corpse - that this martyr would resurrect. This is a question of the narrowest scope, for it questions the fate of an individual being, "this martyr." Therefore, this level can be called ontic.

Ippolit then moves a step further. He considers that the painting proves that "death is so terrible and so powerful, that even He who conquered it in His miracles during life was unable to triumph over it at the last" (Dostoevsky 2002, 599). This is a problem of a broader scope. Unlike the first ontic level, it does not address only Christ. The argument behind this question could be formulated as follows: if Christ's complete immersion in death actually shows that not even his body can escape the power of natural laws, this means that the power of death over human beings is without exception. It is in this sense that Ippolit mentions the "absolute subordination of all men and things to it" (Dostoevsky 2002, 599). Since even Christ is not exempt from this rule, such a conclusion represents a denial of the representative value of Christ's death as the Saviour, as it is, for example, understood by Paul: "For if we have been united with Him in a death like His, we will certainly also be united with Him in a resurrection like His" (Rom 6:5). ${ }^{4}$ Ippolit's problem is precisely the reverse of Paul's belief. Ippolit not only believes that the corpse painted by Holbein highlights Christ's utterly human death, but he goes a step further, finding in such a death no "remnant" or "surplus" that would enable Christ to resurrect. The effect of His helplessness in the face of death then extends to all those who hoped to be saved by Him through His death. In Dostoevsky's preparation notes for The Idiot, the reference to Christ's terrible cry from the cross (PSS 9, 184 ) is immediately followed by a reference to the Dead Christ from Basel. This indicates that Dostoevsky connected this painting with Christ's last words in the Gospel of Matthew (Mt 27:50) and the Gospel of Mark (Mk 15:37); (Skakov 2009, 125).

In this regard, one element of orthodox theology is especially worth mentioning. Ippolit refers to the fact that the early Church, in the centuries following Christ's death, taught that Christ suffered on the cross not only symbolically, but in a very real way. Although he does not state this explicitly, he refers to the response of the Church to Docetism, which emerged as early as the first century, and which held the opposite view, namely that Christ's suffering was only symbolic (Frey 2018, 2749). Certainly, looking at Holbein's painting, the idea that Christ's

\footnotetext{
${ }^{4}$ Special emphasis on Christ's death "for us": Rom 5:8; 8:32; Eph 5:2; Mark 10:45).
} 
suffering is only an illusion is completely ruled out, which has important implications. If Albert Camus is right in claiming that Ivan Karamazov, with his aforementioned rebellion, actually voluntarily "refused salvation" (Camus 1951, 76-83), then Ippolit has a different problem. Holbein's Christ assures him that salvation is not a matter of choice, but that it is simply impossible. Due to the impossibility of Christ's resurrection, each individual human destiny is crushed: death is the end, salvation is impossible, and the eschaton is an illusion. Therefore, this level of Ippolit's message can be called eschatological.

Ippolit mentions that Christ overpowered nature during his life, and that nature obeyed $\mathrm{Him}$ (Mk 4: 35-41; 5: 21-43), but in the end, in his death, nature subjected Him to her rule. If this proves the absolute authority of natural laws, clearly Christ is not the only one affected by them. This part of Ippolit's argument is very modern, representing Christ as the victim of nature: "some enormous mechanical engine which has seized and crushed and swallowed up a great and invaluable Being" (Dostoevsky 2002, 599). In this regard, some authors note that in Ippolit's reference to the „enormous mechanical engine"one should recognize literally - the guillotine (Zink 2010, 422). Ippolit already approaches nihilism with this idea, for the message of Holbein's Christ to the human hope of resurrection is that the world is not as ordered and full of meaning as suggested by Christian neo-platonism and medieval metaphysics.

So, can Holbein's Dead Christ really be considered a symbol of the end of such metaphysics? In answer to this question, an interesting coincidence should be pointed out. Alois Riegl, one of the "founding fathers" of formalism in art history, in his Historical Grammar of the Visual Arts, divided the history of culture into three periods. Particularly interesting is the third period, following ancient Greek anthropomorphic polytheism and Christian monotheism which, according to this periodization, ruled the spirit of the European West beginning with the Edict of Milan, in 313. After this period, Riegl writes, comes the naturalscientific worldview. In this period the view was held, claims Riegl, that nature and the world are no longer ruled by a divine being but by the natural law of causality. So, when, according to Alois Riegel, does this world begin? He is quite specific in his answer to this question: "A distinctly naturalistic worldview can be spoken of only after 1520 . It was especially developed by peoples of purely Germanic origin" (Riegl 1999, 39). Hans Holbein is, of course, a German painter, and Riegel's periodization becomes even more interesting if we recall that Holbein started painting his Dead Christ precisely in tune with Riegl's statement, immediately after 1520 (began in 1521 and finished in 1522). This means 
that, in a symbolic sense, Holbein's Dead Christ could indeed be considered a kind of "firstborn" of the modern era, about which Riegl writes.

By excluding the possibility of the resurrection of Holbein's Christ, nature is presented primarily as a "dark, irresistibly powerful, eternal force" to which everything is subordinated (Dostoevsky 2002, 600). Ippolit's interpretation of the body of Holbein's Christ means that the understanding of nature is no longer connected with the originally Platonic concept of the cosmos. By associating it with the Logos in John 1 , Christianity later perceived the cosmos primarily as benevolent and imbued with the divine, and therefore "enchanted". However, Holbein's Christ is a striking image of the reverse: the cosmos and nature are no longer enchanting. The representative of the new world and its new metaphysics is Max Weber, who announced the famous Entzauberung der Welt, "disenchantment of the world" (Weber 2004, 30). A world affected by such disenchantment no longer confirms the veracity of Psalm 19: 1: "The heavens declare the glory of God; the skies proclaim the work of his hands". As Hans Jonas points out, every crisis of the cosmos, already visible in the example of Gnosticism, is expressed by disturbing the order thereof, by abolishing harmony (Jonas 2001, 242). Holbein's Christ seems to announce just that. His fatal message seems to reveal the very opposite face of nature. It is no longer a reflection of the reasonableness and beauty of the Logos which was "in the beginning" (Jn 1: 1). Nature now shows a different face. In describing it, Alois Riegl, as has already been stated, does note, however, that nature, from the scientific point of view, "is not intentionally hostile" (Riegl $1999,39)$. This is in complete agreement with Ippolit's understanding of nature. He also does not think that nature is intentionally hostile to the body of Christ. In any case, nature is no longer associated with the Logos, with thoughtfulness and beauty. By crushing the body of Christ, through his violent and complete immersion in death, the essence of nature, according to Ippolit, is revealed primarily as "dumb" and "ugly", and destructive of beauty. Robin Feuer Miller rightly wonders whether the closing chapter of The Idiot, with mad Rogozhin next to Nastasja's dead body, is in fact a reflection of Ippolit's idea of the heartless destruction of beauty related to the Dead Christ (Miller 1981, 213).

The final, third level of Ippolit's thought, of the widest conceivable scope, that may be called ontological, seems somewhat vague because it ends in a premonition. He suspects that the disciples, after laying the body of Christ in the tomb, parted in terrible fear, with "each of them carrying within himself one great thought which was never eradicated from his mind for ever afterwards" (Dostoevsky 2002, 599-600). 
Although Ippolit does not specify anything, perhaps we can speculate about what this "great thought" means and what it consists of. This "great thought" could perhaps be inferred from the painting itself, from the belief - as Kristeva writes - that the body of Holbein's Christ "conveys to viewers an unbearable anguish before the death of God, here blended with our own" (Kristeva 2003, 110). This problem was also tackled by Carlo Maria Martini, who concludes the following about the anxiety of the disciples on Holy Saturday: "The prospects for the future were nil, from this catastrophic situation, from the collapse of illusions, there was no way out" (Martini 2000, 16). Joseph Ratzinger emphasizes the same, when speaking of "the terrible mystery of Holy Saturday, the day of the hiddenness of God" (Ratzinger 2000, 38). If this feeling, this "great thought," can indeed be translated into the language of metaphysics, then no one has done this translation better than Friedrich Nietzsche and not just by the mere proclamation of the "death of God" or even by the powerful image that accompanies this revelation, of God's bleeding under our knives. This "translation" is hidden within the question that represents the metaphysical essence of Nietzsche's message about God's death: "Was taten wir, als wir diese Erde von ihrer Sonne losketteten?" (Nietzsche 1999, 481).” „What were we doing when we unchained this earth from its sun?" (Nietzsche 2007, 120). This breaking of the chains means that the world we considered to be our home before God's death, still immersed in the hope of Christ's resurrection, ceases to be our home. This ontological uprooting, the discovery of nonbeing at home, the realization of the non-existence of home, could be the terrible, "great thought" referred to by Ippolit.

If we take a closer look, Prince Mishkin is actually a literal, existential victim of that same condition. He has been absent for years from Russia, which should have been his home, and has become a foreigner there. He admits twice that he "has no one, absolutely no one in Russia." (Dostoevsky 2002, 9, 40). Moreover, reporting on the years he spent outside Russia, in Europe, Prince Mishkin mentions that his illness had worsened (he had epilepsy just like Dostoevsky!), and that he was overwhelmed by unbearable sadness, for everything was foreign to him there. Prince Mishkin therefore suffered due to the fact that he was far from home. Furthermore, it is interesting to note that General Jepanchin says, literally, that Mishkin has no place to lay his head (PSS $8,45)$. This is an obvious allusion to Matthew 8:20, where Christ says the same about himself: "Foxes have dens and birds have nests, but the Son of Man has no place to lay his head". Could it be that the loss of faith which was a result of his seeing Holbein's Dead Christ, and which will be mentioned later by Prince Mishkin, is in fact the same as an 
acknowledgement of the loss of one's home? Is this not the unchained Earth that Nietzsche speaks of? Could this also be the "huge thought" in Ippolit's argument? Perhaps. However, there is a necessary condition for the realization of this possibility: Ippolit's understanding of Holbein's Dead Christ needs to be proven correct. At this point, this possibility must be examined.

\section{Is Ippolit in the right?}

How does the vast literature on Dostoevsky relate to Ippolit's argumentation? In answer to this question, it seems that authors are more frequently inclined to share the horror of his discoveries than to question the validity of his statements. In this context, it is worth recalling Nietzsche's famous 146th aphorism from Beyond Good and Evil: „When you stare for a long time into an abyss, the abyss stares back into you" (Nietzsche 2002, 69). Following Ippolit's remarks on Holbein's Dead Christ, this abyss no longer seems abstract. It seems to have taken on a very specific shape. It stares at the viewer with the face and body of Holbein's Dead Christ. It is impossible to back away from Him. The horror that is born along with this realization is overwhelming. Perhaps this is the reason why "Ippolit's argument" gained many more admirers in the literature on Dostoevsky than might have been expected. However, there is a more fundamental problem: is the basis for his claims about Holbein's Christ valid? Tatiana Kasatkina addressed this question by making parallels with Dostoevsky's actual experience in Basel. In her essay on Dostoevsky and Holbein's Christ, she argued that "reading the message" of the painting literally depends on the angle from which it is viewed; but, can such a thesis be accepted without questioning, and more importantly, can it weaken or even challenge Ippolit's argument?

It is possible to agree that when this painting is viewed from below, it might seem that, from this perspective, the law of gravity is creeping into the dead body of Christ in such a way that it actually threatens to collapse, to fall from the painting onto the observer. Thus, the death of Christ would literally overwhelm the viewer. From this unusual angle, the viewer seems to be even more significantly involved in the painting, just as in the case of Van der Weyden's Deposition from the Cross. ${ }^{5}$ The Flemish master apparently thought of this same effect a century before Holbein, for, a comparison of the different layers of paint in the painting shows that Van der Weyden endeavoured to amplify the impression of

\footnotetext{
${ }^{5}$ Rogier Van Der Weyden: The Descent from the Cross, c. 1435. Oil on oak panel, $220 \times 262 \mathrm{~cm}$. Museo del Prado, Madrid.
} 
the instability of the body of Christ in the hands of his friends. Thus, it seems that not only the body of the dead Christ might fall out of their hands, but that with it, inadvertently dropped towards the spectator, they themselves might fall as well. Although she does not draw the comparison with Van der Weyden, Kasatkina concludes that the body hanging above the viewer "creates the impression of real and just terrifying exhaustion; the eye thrown into the eye socket is deadly still; a crooked arm and a strangely arched shoulder and neck create the impression of torture, a terrible anxiety that does not seem to have ended with death" (Kasatkina 2011, 77).

However, is this analysis in line with Dostoevsky and his experience? First of all, we should be reminded that the characters from The ldiot look at the painting from this perspective, because the copy of Holbein's painting in Rogozhin's house is placed above the door (PSS 8, 181). Such an arrangement in the novel corresponds exactly to the way in which the painting was placed in the Basel Museum when Dostoevsky saw it. Bearing in mind Dostoevsky's well-documented agitation at that moment, it is interesting to recall that in The Diary of 1867, Anna Dostoevska wrote that Dostoevsky "stood on a chair in front of the painting to see the painting better" (Dostoevska 1993, 234). Anna refused to follow his example not only because she did not particularly like the painting, but also because she feared that the museum officials would fine them. Obviously, for Dostoevsky, it was worth taking the risk. If we carefully read the notes of Anna Dostoevska, it seems that her husband simply wanted to have a better look at the painting, and that this is why he reached for a chair. When Kasatkina interprets his move, she adds a detail that cannot be inferred from Anna's writings, namely that Dostoevsky did this knowing that a change of position would fundamentally change one's perception of the painting, since at eye level the body of Christ would seem perfectly stable, and many other details would appear in a different way. In the text by Anna Dostoevska, there is no indication of such an interpretation of Dostoevsky's decision to observe the Dead Christ standing on a chair.

This shift from the biographical account allows Kasatkina to develop a more optimistic interpretation of the painting. She first concludes that from this new, changed standpoint, Christ's muscles seem to be petrified in some effort, and together with the strangely curved neck, from that perspective they seem to form the beginning of a movement that requires enormous, supernatural effort. This beginning of a movement would be the first hint of resurrection. The eyes, instead of being thrown backwards while remaining unclosed in death, now seem to be unconsciously opened at the very first moment 
of the awakening of consciousness, and slowly return under the eyelids, to their natural position. This impression, Kasatkina notes, is also reinforced by the apparent protrusion of the finger of the right hand beyond the surface of the painting into the third dimension, which is then no longer interpreted as announcing the absolute power of death, but the awakening of life. Furthermore, where did the light in the closed grave come from? Kasatkina suggestively asks: "is it not the one who shines from the grave", is it not the light of Christ, who, as in the fourth song of the Orthodox Easter canon, "shines over us from the grave?" (Kasatkina 2011, 79). Such an attempt to dress Holbein's painting in preEaster attire revealed to the viewer by a change of perspective begs the question: could this be an attempt to unlock the meaning of the Dead Christ with the key Holbein offered in one of his later paintings, Ambassadors? ${ }^{6}$ Namely, Holbein painted a prominent skull in the Ambassadors (twelve years after the Dead Christ) whereby he applied the anamorphosis technique which is a distorted projection requiring the viewer to occupy a specific vantage point. In other words, the twodimensional skull placed between the two ambassadors in the painting becomes seemingly three-dimensional if viewed from an elevated point at the far right edge of the image. Could this be an attempt by Kasatkina to save the Dead Christ from Ippolit's argument by trying to apply the principle of anamorphosis to the painting, claiming that it is necessary to carefully choose one's a standing-point in order to correctly read its message?

Going back to the novel itself, Ippolit's argument is not contradicted by a counter-argument of equal or comparable force, at least not in the pages of The Idiot. It will be developed in Dostoevsky's last novel and voiced by Alyosha Karamazov's doubts before the dead body of Starets Zosima in The Brothers Karamazov. This does not mean, however, that Dostoevsky does not play with Easter symbolism around his Christ-like prince in The Idiot. For example, this symbolism is hidden in the name and surname of Anastassya Filipovna Barashkova. The root of the name

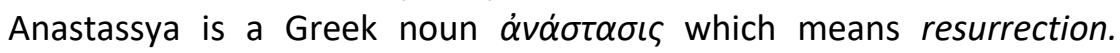
Moreover, her surname, Barashkova, contains the word барашек, which means lamb in Russian. ${ }^{7}$ There are further references to Christ's

\footnotetext{
${ }^{6}$ Hans Holbein the Younger: The Ambassadors, 1533., $207 \times 209,5 \mathrm{~cm}$, Oil on oak, National Gallery, London.

${ }^{7}$ I would like to thank Professor Stephan Lipke, the head of the Thomas Aquinas Institute in Moscow, for these remarks. It should be added that in the New Testament used by Dostoevsky, the famous volume that he received from pious women while traveling to Siberia, another Russian word for lamb appears. For
} 
Passover sacrifice in the words used to anticipate Nastasja Filipovna's tragic death. This is especially important since some authors consider her to be an "image of Christ" in The Idiot (Oenning Thompson 2001, 74). The violent manner in which she died is therefore not accidental. It is first announced by Prince Mishkin, at the very beginning of the novel (PSS 8, 32), and then later by Rogozhin himself (PSS 8, 177). They both use the same Russian verb, зарезать. Although the Russian translation of Isaiah 53: 7 does not use this term, but rather заклание, it seems that the aforementioned verb from The Idiot could still be linked with Christ's Passover sacrifice: "he was led like a lamb to the slaughter". Rogozhin's second, even more direct "prophecy" about Nastasja Filipovna's death also has a violent connotation: "she is going to marry me, because she knows for certain that the knife awaits her" (Dostoevsky 2002, 311). Based on these insights, allusions to the resurrection in The Idiot seem indisputable. Yet, they cannot be the answer to a more fundamental question: is it possible to discern such allusions to resurrection on the very body of Holbein's Dead Christ? This is a key question, because neither the allusions to resurrection from The ldiot nor the possible experiments with perspective before Holbein's Dead Christ have enough power to sufficiently and proportionately counterbalance Ippolit's argument. So, does such a counter-argument even exist?

It seems that it does. Neither Dostoevsky in Basel nor Ippolit in the novel have made that observation, yet there is a key detail on the neck of Holbein's Dead Christ. Namely, an anatomical analysis of this part of the dead body of Christ shows that, despite its asthenic body type, the Adam's apple is not depicted on the neck ${ }^{8}$. It is hard to believe that, being such an expert in anatomy, Holbein would have failed to paint the Adam's apple out of negligence or ignorance. It seems much more likely that this omission should be attributed to a reason which is clearly theological. Christ is the new Adam (Heb 2: 5-9). Unlike the old Adam and his companion from Eden, as well as all of their descendants, there is nothing that could become lodged in Christ's throat and become the

example in Jn 1,29:,,се, Агнец Божий, вземляй грехи мира“; Господа нашего Иисуса Христа Новый завет. Первым изданием, ВТип. Российского Библейского Общества, Санктпетербургъ 1823., р. 215.

${ }^{8}$ For this anatomical analysis, I thank Professor Lovorka Grgurevic from the Drago Perović Department of Annatomy, School of Medicine, University of Zagreb. 
anatomically visible symbol of original sin. This would suggest that the absence of the Adam's apple from the body of Holbein's Dead Christ could be interpreted as proof that Christ, albeit immersed in death, remains the Saviour and that, despite being physically crushed, $\mathrm{He}$ is about to be resurrected. If this hypothesis regarding the theological basis for the absence of the Adam's apple from the neck of Holbein's Christ is accepted, it could challenge the very essence of Ippolit's argument. This means that an obvious Messianic element is retained on the body of Holbein's Dead Christ, and that, consequently, he is not completely immersed in death.

\section{Conclusion}

Based on the arguments presented, the following three conclusions can be drawn:

1. A hermeneutic analysis of Ippolit Terentyev's discourse on the painting The Dead Christ by Hans Holbein shows that his argumentation consists of three levels: the ontic, eschatological and ontological, all of which have nihilism as a common denominator.

2. An analysis of the sources on Dostoevsky's stay in Basel as well as references to Holbein's Christ, especially in The ldiot, lead us to conclude that it does not seem likely that Dostoevsky had in mind what was later formulated by Tatiana Kasatkina as the hypothesis on a changing meaning based on one's physical perspective. In order to understand the Dead Christ and to recognize the details that point to the resurrection, the angle from which the painting is observed is not crucial.

3. Ippolit's nihilistic conclusion about Holbein's Dead Christ can be contrasted with a key detail from an anatomical analysis of the body of the Dead Christ. Starting from the premise that the absence of the Adam's apple from the neck of the Dead Christ is intentional, this absence can be interpreted from a theological perspective: Christ is the new Adam, and He is deprived of the symbolic consequence of $\sin$. This means that, contrary to Ippolit's argument, the power of death over Holbein's Christ is not absolute, and He remains the resurrected Saviour.

\section{Works Cited}

Bitjugova, I. A, Viktorovič, V. A., Kijko E. I., Ornatskaja T. І. (И. А. Битюгова, В. А. Викторович, Е. И. Кийко, Т. И. Орнатская). Летопись жизни и творчества ф. М. Достоевского, том второй 1865-1874. Издательство Академический проект, СанктПетербург 1999. 
Brouwer, Rinse Reeling. "Kenosis in Philippians 2: 5-11 and in the History of Christian Doctrine," in: Zijlstra, Onno: Letting Go. Rethinking Kenosis, Peter Lang, Bern 2002.

Camus, Albert. „Le refus du salut“, in: Camus, Albert: L'Homme Revolte, Gallimard, Paris 1951.

Dostoevskaja, Anna Grigorjevna (Анна Григорьевна Достоевская). Воспоминания. Издательство Правда, Москва 1987.

Dostoevskaja, Anna Grigorjevna (Анна Григорьевна Достоевская). Дневник 1867 года, Наука, Москва 1993.

Dostoevsky Fyodor Mihailovič (Федор Михайлович Достоевский). Полное собрание сочинений в тридцати томах (PSS): Том 8. Идиот, Наука, Москва 1973.

Dostoevsky, Fyodor Mihailovič (Федор Михайлович Достоевский). Полное собрание сочинений в тридцати томах (PSS): Том 14. Братья Карамазовы. Книги 1-10, Наука, Ленинград 1973.

Dostoevsky, Fyodor Mihailovič (Федор Михайлович Достоевский). Полное собрание сочинений в тридцати томах (PSS): Том 9. Идиот: рукописные редакции ; Вечный муж ; Наброски, Наука, Ленинград 1974.

Dostoevsky, Fyodor. The Idiot, Translated by Richard Pevear and Larissa Volokhonsky, Everyman, London 2002.

Dostoevsky, Fyodor. Idiot (Oxford World Classics), Translated by Alan Myers, Oxford University Press, Oxford 2008.

Frank, Joseph. Dostoevsky: A Writer in His Time, Princeton University Press, Princeton 2009.

Frank, Joseph. Lectures on Dostoevsky, Princeton University Press, Princeton and Oxford 2020.

Frey, Jörg. "'Docetic-like' Christologies and the Polymorphy of Christ. A Plea for Further Consideration of Diversity in the Discussion of "Docetism", in: Verheyden, Joseph (Ed.). Docetism in the Early Church. The Quest for an Elusive Phenomenon, Mohr Siebeck, Tübingen 2018.

Jonas, Hans. The Gnostic Religion, Beacon Press, Boston 2001.

Karamzin, Nikolaj (Никола́й Миха́йлович Карамзин): Письма русского путешественника, Наука, Ленинград 1984.

Kasatkina, Tatiana. „After Seeing the Original“, in: Russian Studies in Literature, Vol. 47(2011.), No. 3.

Kristeva, Julia. Black Sun: Depression and Melancholia, Columbia University Press, New York 2003.

Martini, Carlo Maria. Gospa Velike subote, Katehetski salezijanski centar, Zagreb 2000. 
Max Weber. "Science as a Vocation«, in: The Vocation Lectures, Hackett Publishing Company, Indianapolis/Cambridge 2004.

Miller, Feuer Robin. Dostoevsky and The Idiot. Author, Narrator and Reader, Harvard University Press, Cambridge and London 1981.

Miščin, Daniel. „Odrazi Holbeinove slike Tijelo mrtvog Krista u grobu u romanima Idiot i Braća Karamazovi F. M. Dostojevskog", in: Obnovljeni život, Vol. 75, No. 3(2020).

Miščin, Daniel. U potrazi za svetim. Svjetlo s istoka i imanencija transcendencije, Školska knjiga, Zagreb 2011.

Nietzsche, Friedrich. Beyond Good and Evil, Cambridge University Press, Cambridge 2002.

Nietzsche, Friedrich. Morgenröte/ Idyllen aus Messina/ Die fröhliche Wissenschaft, KSA 3, Editors: Giorgio Colli and Mazzino Montinari, Deutscher Taschenbuch Verlag/ de Gruyter, München 1999.

Nietzsche, Friedrich. The Gay Science, Cambridge University Press, Cambridge 2007.

Oenning Thompson, Dianne. „Problems of the Biblical word in Dostoevsky's poetics", in: George Pattison and Dianne Oenning Thompson (Ed.): Dostoevsky and the Christian Tradition, Cambridge University Press, Cambridge 2001.

Pattison, George. Kierkegaard, Religion, and the Nineteenth-Century Crisis of Culture, Cambridge University Press, Cambridge 2002.

Ratzinger, Joseph and Congdon William. The Sabbath of History, The William G. Congdon Foundation, Washington D.C. 2000.

Riegl, Alois. „Historijska gramatika likovnih umjetnosti“, in: Snješka Knežević (Ed.): Bečka škola povijesti umjetnosti, Barbat, Zagreb 1999.

Skakov, Nariman. „Dostoevsky's Christ and Silence at the Margins of The Idiot", in: Dostoevsky Studies, New Series, Vol. XIII (2009).

Wasiolek, Edward (Ed.). Fyodor Dostoevsky: The Notebooks for The Idiot, Dover Publications, Mineola, New York 2017.

Zink, Andrea. „The culture of justice: reflections on punishment in Dostoevsky's The Idiot", in: Studies in East European Thought, Vol. 62, No. 3/4, Crossing Boundaries: Russian Discourses on Culture (November 2010). 


\section{F. M. DOSTOJEVSKI I NIHILISTIČKO TUMČENJE HOLBEINOVE SLIKE „MRTVI KRIST U GROBU”}

Otkad je dovršena 1522. godine, nad slikom Mrtvi Krist u grobu Hansa Holbeina mlađeg lebdi pitanje: koja je poruka tog mrtvog tijela? Nakon što je 1847. video tu sliku, ruski klasik Fjodor Mihajlovič Dostojevski bio je također zaokupljen tim pitanjem. Sustavan i izravan odgovor na to pitanje nastoji dati Ippolit Terentyev u romanu Idiot. Provodeći hermeneutičku analizu tog njegova izlaganja, autor ovog članka uočava da se njegova pozicija može nazvati nihilističkom. Tim nihilizmom zahvaćene su sve tri razine u Ippolitovu izlaganju: ontička, eshatološka i ontološka. No, ostaje pitanje: može li se taj nihilizam opravdati samom slikom? Zanimljivo je postaviti to pitanje u kontekstu periodizacije europske kulture Aloisa Riegla. On smatra da je nakon razdoblja kršćanskog monoteizma, treće i posljednje razdoblje u razdoblju europske kulture prirodoznanstveno. To razdoblje, smatra Riegl, počinje 1520. Prihvatimo li tu periodizaciju, Mrtvi Krist može se smatrati jednim od prvih izdanaka modernog svijeta, imajući na umu da je Holbein tu sliku slikao 1521. i 1522. godine. S obzirom na pitanje je li tijelo Mrtvog Krista, kako misli Ipolit, toliko potopljeno u fizičku patnju da to isključuje mogućnost uskrsnuća, ovaj članak nudi neke anatomske razloge s mogućom teološkom pozadinom koji niječu valjanost Ipolitove moderne, nihilističke hipoteze o smislu Holbeinova Mrtvog Krista.

Ključne riječi: Dostojevski, Holbein, Ipolit Terentjev, smrt, nihilizam, Isus Krist, uskrsnuće 